\title{
Impact of Job Characteristics on Job Performance with the Moderating Role of Perceived Supervisor Support: Manufacturing Companies in Jordan
}

\author{
Angham Saleem Obeed Alma'aita and Abdul Aziz Abdullah
}

Faculty of Economics and Management Science, Universiti Sultan Zainal Abidin, Kuala Nerus, Terengganu, Malaysia. *Corresponding author. Email: prognagham@gmail.com

\begin{abstract}
This study intends to explore job related characteristics that influence employee performance i.e., "employee empowerment, communication, job security, and job environment". It will also explore the moderating role of supervisor support that modifies the employee attitude towards job performance in large industrial companies in Jordan. Moreover, with the use of social member exchange and motivational theories, the theoretical framework of this study is justified. Empirical evidences from a broad strand of performance literature will validate the significant and theoretical justification of this research. The research design of this study will consist of two phases and will involve both qualitative and quantitative research approaches. The expected results of the examination of the Impact of Job Characteristics on Job Performance with the Moderating Role Perceived supervisor Support: Manufacturing Companies in Jordan.
\end{abstract}

Keywords: Job characteristics, employee empowerment, communication, job security, job environment, job performance, supervisor support

\section{INTRODUCTION}

The fundamental goal of HR in an organization is to effectively manage its employees by encouraging positive attitudes like increasing productivity, job satisfaction, motivation and organizational citizenship behavior and reducing negative employee attitudes like increased turnover, absenteeism and deviant work place behavior. These factors collectively describe an individual employee's performance at work. employee performance has a direct relation to an organization's overall performance and success [1]. Hence, it is important for organizations to ensure that the employees are motivated to perform at their highest potential.

Rsearch on reff [2] stated that every individual employee is motivated by a different incentive be it internal or external, monetary or non-monetary by its nature. The study further stated that non-monetary methods such as appreciation, recognition, job enrichment, employee empowerment, work-life balance are the preferred methods of motivating work force during weak economic conditions the organization faces. In their studies of six major situations across the globe have identified that nonmonetary strategies remained widely popular technique in motivating the employees at the time of crisis [3]. That employee empowerment has been most preferred option in many organizations during the time of business decline [4]. Employee empowerment is such a process, as defined by management theorists, which not only encourages employees but also the management to maximize the utilization of their skills and expertise explained that employees of any organization that feel empowered work with better efficiency and help the organization to achieve its ultimate goals [5]. Those organizations cannot achieve high performance of their employee just by simply focuses on wages and salaries that can be the alternative of their efforts but not promote innovation, utmost efficiency and creativity at workplace [6]. 


\section{LITERATURE REVIEW}

\subsection{Problem Statement}

High employee turnover is a crucial factor that is effecting the industrial sector in Jordan. The survey report suggested that main reason for high employee turnover is less job satisfaction and absence of essential job characteristics that are necessary for employee retention. This may pose a serious threat to highly growing sector in Jordanian Economy.

These companies is that the number of employees in these three companies in Jordan is not stable yearly. More specifically, the employees' number in Jordan Phosphate Mines Company is changing every year-end. This company reported losses of around \$30.11 million in 2016 even though it has established a new branch in Indonesia in 2014.

In the Arab Potash Company, the number of employees in 2018 was 1789, while it was 1811 in 2017 and 1925 in 2016. It shows that every year, employees are leaving their jobs due to low job satisfaction since this is more important problem it should be investigated and considered solutions to stop this. investigated among the employees of Arab Potash Company (APC). recommended more studies to enhance employee satisfaction [7].

As for the Lafarge Cement Company, the number of employees in 2015 was 569, whereas it was 596 in 2017 and 580 in 2018. problems that face Lafarge Cement Company (LCC) and recommended paying greater attention to employee involvement in the company as they are seen as the cornerstone to the companies' success [8]. About the change in employees' numbers, this change could affect the organization negatively. Due to changes and reduce in employees' numbers, it can be possible that employees are leaving jobs due to low job satisfaction and less engagement and involvement. This can affect company because there is less job security and employees feel less satisfaction and this in turn results in low job performance.

Job performance is a significant factor in any organization as it determines the overall performance of the organization. Due to increased competition and variety of ongoing opportunities with fastest internet communication systems, organizations are facing challenges in retaining high performing employees. These challenges are: every employee wants a good compensation and benefits from his job. Day by day, these expectations are going higher and higher. Second challenge is employees expect a welldefined Career Path which defines whether they will stay with the organization for a longer duration. So, compensation is one of the major for affecting employee retention in any organization. There are numerous studies that discussed the social and psychological factors that contribute towards employee retentions [9]-[10]. An important challenge for which organizations are struggling in 21 st century is monitoring and provision of internal workplace settings that will contribute towards improved job performance of existing employees.

The above literature indicated that there is effect of job characteristics on employee job performance. But the previous data revealed that there is extensive research on organizational factors and employee job performance but there is no specific study about the role of job characteristics in increasing employee job performance. The present study can be a pioneer study in this aspect. The present study will try to bridge the gap between literature on necessary job characteristics and current status of job characteristics in Jordanian Industrial Sector.

\section{RESULTS AND DISCUSSION}

This study is intended to explore job related characteristics that influence employee performance. In Large industrial companies in Jordan, as compare to SMEs, the HRM functioning is more standardized whereas the SMEs face more issues regarding employee performance [11]. Among all possibilities of low performance employee attitude also matters a lot as employee attitude reveals the extent to which particular employee is psychologically willing to unleash his energies, efforts and capabilities on his job for the advantage and benefits organization.

On the basis of social exchange theory argued that the job related sociological factors contribute substantially toward enhancing job satisfaction and job performance [12]. There are various evidences that have supported the impact of job characteristics on job performance [13]. However, moderating role of perceived supervisor support is not explored before in context of social exchange and motivational theories.

\subsection{Concepts and Variable Discussion}

\subsubsection{Job Performance}

Job performance in organizational context is simply refers to the answer of how employee or worker performs at job or work [12]. The concept of Job performance in literature stated as the net outcome of individual efforts that commence with capabilities and knowledge of tasks which presents the amount of achievement and accomplishment of the function of tasks [14]. Finally, the concept and meaning of job performance can be labeled as results or outcomes of an employee against assigned task [15]

\subsubsection{Job Empowerment}

Defined employee job empowerment as submission of control, autonomy and information to participate in job related decision-making and other organizational affairs. "Job empowerment occurs when an employee tends to 
share his information, enhances intellectual capabilities to gain autonomy while making decisions" [16].

\subsubsection{Interpersonal Communication}

In organizational behavior literature the construct of Interpersonal communication is defined as "involving real time face to face or voice to voice conversation that allows instant feedback in the organization" [17]. Moreover, it can be stated as the extent or degree to which employees perceive adequacy and satisfaction with respect to presence of information and communication within work environment [18].

\subsubsection{Job Security}

"Job security refers to an employee's expectations about the stability and longevity of his or her job in an organization" [19].

\subsubsection{Job Environment}

Provision of conducive job environment embraces provision of a positive working conditions or environment to avoid conflicts plus ability to deal and combat with unacceptable work behaviors [20]. A positive work environment attributed with shared fairness and facilitation to report unacceptable situation.

\subsubsection{Perceived Supervisor support}

In literature perceived supervisor support (PSS) is stated as "the degree to which a subordinate feels that he/she is supported and respected by his/her supervisor" [21]. The PSS is also the perception of employees about their readiness and willingness to support or help subordinates.

\section{CONCLUSION}

Accordingly, institutions and companies must understand the things that satisfy their employees and how these organizations can increase employee satisfaction with their jobs and thus increase their performance towards their jobs, which is what the current study tries to investigate among its employees. These functional characteristics will be an important factor that must be addressed effectively as it improves productivity and develops the company in a way that achieves its own goal. Empowerment practice of providing employees with information about goals and performance also has a huge positive impact on job performance. This proves that employee empowerment has an important role that it can play to increase employee job satisfaction.
The study is expected to bring about the relationship among empowerment, job performance, job security, job performance, interpersonal communication and job performance, perceived supervisory support and employee empowerment. This study will also see the effect of perceived supervisor support on this relationship. It also seeks to determine whether perceived supervisor support strengthens or weakens this relationship.

\section{REFERENCES}

[1] F. Luthans, S. M. Norman, B. J. Avolio, J. B. Avey. The mediating role of psychological capital in the supportive organizational climate-employee performance relationship. Journal of Organizational Behavior: The International Journal of Industrial, Occupational and Organizational Psychology and Behavior, 29 (2) (2008) 219-238. DOI: https://doi.org/1 0.1002/job.507

[2] A. A. A. Kerdasi, S. F. Azam. The Impact Of NonMonetary Incentive On Employees Commitment In Telecommunication Sector In Libya. Palarch's Journal Of Archaeology Of Egypt/Egyptology, 17 (9) (2020) 7781-7798.

[3] A. Cenci. A qualitative viewpoint on the Southern eurozone highly skilled labour mobility in the metropolitan area of Copenhagen in times of crisis and austerity. Mobilities, 13 (4) (2018) 551-568. DOI: https://doi.org/10.1080/17450101.2017.1383665

[4] J. C. Picken. From startup to scalable enterprise: Laying the foundation. Business Horizons, 60(5) (2017) 587-595. DOI: https://doi.org/10.1016/j.bushor.2017.0 5.002

[5] M. Ewing, L. R. Men, J. O’Neil. Using social media to engage employees: Insights from internal communication managers. International Journal of Strategic Communication, 13 (2) (2019) 110-132. DOI: https://doi.org/10.1080/1553118X.2019.1575830

[6] S. I. S. Al-Hawary, A. S. Mohammad, M. S. AlSyasneh, M. S. F. Qandah, T. M. S. Alhajri. Organisational learning capabilities of the commercial banks in Jordan: do electronic human resources management practices matter? International Journal of Learning and Intellectual Capital, 17 (3) (2020) 242 266. DOI: https://doi.org/10.1504/IJLIC.2020.109927 
[7] S. Allahawiah, H. Al-Mobaideen, K. al Nawaiseh. The impact of information technology on knowledge management processes: an empirical study in the Arab Potash Company. International Business Research, 6 (1) (2013) 235. DOI: http://dx.doi.org/10.5539/ibr.v6n $1 \mathrm{p} 235$

[8] A. H. Al-Ali, A. Abu-Rumman. The role of total quality management in the face of challenges: A study in Lafarge-Jordan. Academy of Strategic Management Journal, 18 (1) (2019) 1-16.

[9] M. A. Al-Qeed, M. A. Al-Raggad, M. S. Al-Shura, N. M. AlQaisieh, Z. F. Al-Azzam. The impact of ideal employee award on the retention of distinctive competencies in public sector organizations in the Hashemite Kingdom of Jordan: A field study of public sector employees who obtained the Ideal Employee Award Civil Service Bureau. International Journal of Business and Social Science, 7 (3) (2016) 104-114.

[10] M. F. Almaaitah, Y. Harada, M. F. Sakdan, A. M. Almaaitah. Integrating Herzberg and social exchange theories to underpinned human resource practices, leadership style and employee retention in health sector. World Journal of Business and Management, 3 (1) (2017) 16-29. DOI: http://dx.doi.org/10.5296/wjbm. v3i1.10880

[11] K. Al-Hyari. Lean bundles within Jordanian manufacturing SMEs and their effect on business performance. Problems and Perspectives in Management, 18 (2) (2020) 302-312. DOI: https://doi. org/10.21511/ppm.18(2).2020.25

[12] J. Shen, C. Tang. How does training improve customer service quality? The roles of transfer of training and job satisfaction. European management journal, 36 (6) (2018) 708-716. DOI: https://doi.org/10. 1016/j.emj.2018.02.002

[13] F. Gao, J. Wang, S. Wang. Understanding knowledge workers' job performance: a perspective of online and offline communication networks. Enterprise Information Systems, 13 (1) (2019) 107-131.

[14] S. I. Al-Hawary, N. A. Banat. Impact of motivation on job performance of nursing staff in private hospitals in Jordan. International Journal of Academic Research in Accounting, Finance and Management Sciences, 7 (2) (2017) 54-63. DOI: https://doi.org/10.6007/IJARA FMS/V7-I2/28
[15] R. K. Pradhan, L. K. Jena. Employee performance at workplace: Conceptual model and empirical validation. Business Perspectives and Research, 5 (1) (2017) 69-85. DOI: https://doi.org/10.1177/2278533716 671630

[16] J. Hanaysha, P. R. Tahir. Examining the effects of employee empowerment, teamwork, and employee training on job satisfaction. Procedia-Social and Behavioral Sciences, 219 (2016) 272-282. DOI: https:// doi.org/10.1016/j.sbspro.2016.05.016

[17] U. N. Saraih, M. F. A. Sakdan, K. M. Karim. The Relationships between Interpersonal Communication, Task Design and Job Performance. Asia Proceedings of Social Sciences, 2 (3) (2018) 49-53. DOI: https://doi. org/10.31580/apss.v2i3.253

[18] K. L. Fonner, M. E. Roloff. Why teleworkers are more satisfied with their jobs than are office-based workers: When less contact is beneficial. Journal of Applied Communication Research, 38 (4) (2010) 336361. DOI: https://doi.org/10.1080/00909882.2010.5139 98

[19] C. Q. Lu, D. Y. Du, X. M. Xu, R. F. Zhang. Revisiting the relationship between job demands and job performance: The effects of job security and traditionality. Journal of Occupational and Organizational Psychology, 90 (1) (2017) 28-50. DOI: https://doi.org/10.1111/joop.12158

[20] A. R. Qureshi. Estimating The Resultant Of Office Design Of Employee Performance: Evidence From Employees From Nadra. Ajss, 4 (1) (2020) 60-84.

[21] S. Gok, I. Karatuna, P. O. Karaca. The role of perceived supervisor support and organizational identification in job satisfaction. Procedia-Social and Behavioral Sciences, 177 (2015) 38-42. DOI: https:// doi.org/10.1016/j.sbspro.2015.02.328 